\title{
Structural Change and Industrial Policy in Turkey
}

\author{
İzak Atiyas and Ozan Bakis ${ }^{1}$
}

Forthcoming, Emerging Markets Finance and Trade, 2014

\begin{abstract}
This paper presents evidence on structural change in Turkey and provides an overview of the evolution of industrial policy in the last three decades. Turkey has experienced substantial growth in labor productivity in the last decade. About two thirds of the increase in aggregate labor productivity arises from reallocation of employment from low to high productivity sectors and one third from productivity increases within sectors. Decomposition of productivity growth using micro-data also reveals an important contribution from reallocation. We also document substantial change in the composition of exports. We argue that structural change was not a direct result of selective industrial policy, simply because the incentive system displayed little sectoral selectivity during the period when major structural change took place.
\end{abstract}

\section{Introduction}

The purpose of this paper is to examine various aspects of structural change in Turkey and present an overview of the evolution of industrial policy especially in the last three decades. Turkey experienced high growth rates in the last decade. We provide data below that suggests that these growth rates entailed substantial growth in labor productivity as well as significant change in the composition of employment, value added and exports. Rodrik (2010) showed that aggregate productivity growth in Turkey contains significant structural change, that is, allocation of labor from low to high productivity sectors. We corroborate this result using both aggregate (national income) and micro data. We document significant changes in the composition of value added and employment within the manufacturing industry and in the composition of exports.

\footnotetext{
${ }^{1}$ Izak Atiyas: Sabanci University and Tusiad-Sabanci University Competitiveness Forum; izak@ sabanciuniv.edu. Ozan Bakis: Tusiad-Sabanci University Competitiveness Forum; bakis@ sabanciuniv.edu. Address: Sabanci University, Orta Mahalle, Tuzla 34956, Istanbul, Turkey.

We would like to thank Zeren Taşpınar, Damla Yıldız and Çağlar Kaya for excellent research assistance. We are grateful to TurkStat for providing access to the micro data set and for providing an excellent research environment. We are grateful for helpful comments to Ali Kutan, Asaf Savaş Akat, Hasan Ersel, Ahmed Galal, Ege Yazgan and an anonymous referee. We also thank participants in the Economic Research Forum (ERF) Workshop on "Structural Transformation and Industrial Policy in Selected MENA Countries" in Istanbul, and in the Conference on MENA Economies as well as an economics seminar at Bilgi University. This paper is based on a project that received financial assistance of the European Union within the context of the FEMISE association and through the ERF. The contents of this document are the sole responsibility of the authors and can under no circumstances be regarded as reflecting the position of the European Union. All remaining errors and omissions are ours.
} 
We also present an overview of industrial policy in Turkey. In particular, we discuss phases when investment and employment incentives contained sectoral selectivity, and when they were (more or less) neutral across sectors (but not across regions). One wonders to what extent industrial policy was responsible for structural change described above. Even though we do not provide any conclusive evidence, we do argue that a substantial part of these compositional changes actually occurred in a period when the incentive system lacked major selectivity across industries. At least for the time being we are led to conclude that structural change owed little to industrial policy. We do report, however, some evidence that regional incentives in the 2000s did have an effect on employment growth on a regional basis.

High growth in labor productivity notwithstanding, the performance of the Turkish economy in the last decade does have limitations. Even though exports have increased and diversified substantially the degree of sophistication of export products is not very high. Similarly, while the share of products with medium level technological content in total exports has increased over time, the share of products with high technological content is still very low. Moreover, there is also evidence that especially those sectors that have expanded most rapidly in the last decade have relatively weak backward linkages and import relatively larger portion of inputs such as raw materials and components. We review evidence and identify these shortcomings.

The paper is organized as follows. In section 2 we provide a brief overview of the macroeconomic and policy background. In section 3 we provide evidence on various aspects of structural change. Section 4 presents a discussion of the evolution of industrial policy as well as a general evaluation. Section 5 concludes the paper.

\section{The macroeconomic and policy environment}

Up until 1980, Turkey followed what is generally known as an import substitution industrialization (ISI) strategy. This was an economic policy regime characterized by very high protection from imports, heavy controls on domestic prices, a repressed financial system, dominance of state owned enterprises in banking and what were seen as critical industries. ISI ended in a deep crisis at the end of the 1970s. A radical economic program was launched in January 1980 following a military coup and was more or less followed through persistently ever since. Hence the 1980s witnessed a fundamental transformation in the economic policy regime from import substitution industrialization towards trade liberalization, liberalization of domestic goods and financial markets, and liberalization of international finance. Foreign trade was liberalized first, during early and mid-1980s. Capital account liberalization was enacted in 1989 and implemented in 1990. A major step towards further liberalization was undertaken in 1996 through a Custom's Union (CU) with the European Union (EU). Between 40-50 percent of Turkey's exports in the last decade and a half have been made to EU countries, though this ratio has declined somewhat during and after the global crisis. 
Liberalization was not accompanied by stabilization. Especially after 1987 and during much of the 1990s Turkey suffered high inflation rates, high real interest rates, high budget deficits and rapidly accumulating public debt. Budget deficits were primarily financed through issuance of government securities which were primarily held by the banking system. Banking supervision and regulation was especially weak. Arbitrage opportunities offered by very high domestic interest rates induced the banking system to increase their foreign exchange risk over time. These developments culminated in a severe crisis in 1999-2000 during which almost half of the banking system was wiped out.

A "recovery program" program was launched in 2001 by the coalition government that was in power when the crisis occurred. Most of the reform elements contained in the program were subsequently adopted or continued with little change by the Justice and Development Party (Adalet ve Kalkınma Partisi, AKP) government that came to power after the elections of November 2002.

The post-2002 macroeconomic environment was radically different from the earlier two decades of liberalization. ${ }^{2}$ Between 2002-2010 GDP in Turkey grew at an average rate of 5.1 percent. The ratio of net public debt to GDP was reduced from 66 percent in 2001 to an average of 30 percent in 2008-2010. Inflation as measured by the annual rate of change of the GDP deflator was reduced from 53 percent in 2002 to 6-7 percent at the end of the decade. Real interest rates which were above 15 percent in 2001-2002 declined and remained below 5 percent after 2009 . The banking system was consolidated and recapitalized, supervision and regulation of the banking system improved dramatically. With the establishment of macroeconomic stability the share of credits in total bank assets increased from around 30 percent in 2003 to around 50 percent in 2010 (Atiyas and Bakis, 2011). Anecdotal evidence suggests that access to credit improved substantially over the last decade, even for small and medium enterprises (SMEs). There is also evidence of improvements in institutions of economic policy through a strengthening of the legal and regulatory infrastructure necessary for the proper functioning of a modern market economy: measures were taken to curtail the discretionary powers of the government (partly by delegation of substantial rule making authority to independent regulatory authorities) to, strengthen the independence of the Central Bank and improve transparency overall (Atiyas 2012).

These developments took place in an overall international environment that was highly benign if not positively conducive to growth. The 2000s witnessed increased capital flows to emerging markets thanks to low interest rates in the US. In addition, in 2004 Turkey started accession talks with the EU. With improvements in the legal and regulatory infrastructure, these developments created a more favorable environment for foreign direct investment, which increased significantly in the 2000s, especially through privatizations.

\footnotetext{
${ }^{2}$ See Akat and Yazgan (2013) for an evaluation of Turkey's recent economic performance. For an overview of monetary policy see Ersel and Özatay (2008). Kılınç et. al (2012) discuss the resilience of the Turkish economy during the recent global crisis.
} 
Two major macroeconomic problems that Turkey has been facing, and which have not been resolved in the last decade are high current account deficit, and high unemployment rates. Indeed, in the last decade as well growth has been accompanied by high current account deficits, hovering around 5-10 percent of GDP between 2005-2011 (except for 2009 when growth rate of GDP was negative). Similarly, the unemployment rate was almost constant and above $10 \%$ during 2000s characterized by a relatively stable growth period. The fact that intermediate goods make up a large portion of total imports has recently led the government to entertain the idea that industrial policy may be one of the policy tools that may be used to attack the current account deficit and unemployment problems. The current account problem will be further discussed below.

\section{Documenting structural change}

The average income in Turkey has grown in a more uninterrupted and less erratic manner in the last decade relative to the earlier 2-3 decades. Per capita income was about 2000 US\$ (PPP 2005 prices) in the second half of the 1970s; it was around 4000 US\$ in the second half of the 1990s, and has reached a level of around 10,000 US\$ by 2010. Clearly the last decade has been a period of more rapid growth than the earlier 2-3 decades.

Table 1 shows average growth of labor productivity (calculated as arithmetic average of annual $\log$ differences of GDP in constant TL prices divided by employment) over the 1980s, 1990s and 2000s. We provide two different periodizations. In the first one average labor productivity growth is presented in terms of calendar decades. In the second one, which we believe is more meaningful, the first period 1981-1989 covers the reform period prior to the liberalization of the capital count. The second period covers up to the end of 2001, including the crisis year, which appropriately belongs to the regime of the 1990s. The third period covers the years when the AKP has been in government. The 1980s appear to be a period of relatively high growth of labor productivity, though part of that is probably rebounding up from the crisis years in the second half of the 1970s. Average growth in productivity of labor almost doubled in the 2000s relative to the 1990 s.

[Table 1 about here]

Productivity growth in the 2000s has been high in international comparison as well. In the working paper version of this paper, Atiyas and Bakis (2013) show that growth of labor productivity in Turkey in the 2000s has been quite high relative to many Central European and Latin American countries, but not as high as that in countries such as Romania, India and China.

\subsection{Structural change: Aggregate (national income) data}

Improvements in overall productivity are often associated with structural change, that is, relatively higher growth of inputs and output in relatively higher productivity industries. 
Atiyas and Bakis (2013) examine the change in the composition of GDP in current prices and document the persistent decline in the share of agriculture and the persistent increase in the share of services. The share of industry increases from about 16-17 percent of GDP in 1968 to about 22-23 percent in the new millennium. In the case of industry one notices a relative decline after the 1990s; indeed, a closer inspection of the data reveals that the share of industry reaches a maximum of 28 percent in 1998 but declines to about 22-23 percent towards the end of 2000s. The share of manufacturing is about 17-18 percent of GDP in the 2005-2011 period.

The category "services" is made up of a heterogeneous set of activities. A closer look at national accounts data in current prices reveals two important changes for the period 1998-2011: the share of financial intermediation declined from about 8-10 percent of GDP to about 4 percent of GDP and the share of "home ownership and dwelling" increased from about 4-5 percent of GDP to about 10-12 percent. The former probably represents the impact of the 2000-2001 crisis on the financial sector during which a sizeable portion of the banking system was wiped out. There is an increase in the share of "transport, storage and communication" as well, from below 12 percent to close to 14 percent for most of the last decade.

Looking at sectoral composition of GDP in constant prices provides a somewhat different picture. In constant prices, the share of industry has increased from around 18 percent at the end of 1960s to about 26-27 percent in 2005-2011, with the share of manufacturing hovering about 23-24 percent in the latter period. By contrast, the share of home ownership and dwelling remains at about 4-5 percent. Hence part of the movement in sectoral shares expressed in current prices reflects rapid increases in household rental prices in the last decade, relative to manufacturing industry prices.

Paralleling the change in the composition of GDP, the composition of employment has changed as well (Atiyas and Bakis, 2013). Sectoral data show a steady decline in agricultural employment from about 47 percent in 1988 to about 25-26 percent in 2010. The decline in the share of agriculture was steeper in the 2000s relative to the 1990s: about 7 percentage points between 1990-1999 and 15 percentage points between 2000-2009. There is a steady corresponding increase in the share of employment in services from less than 40 to over 55 percent in the same period. The increase in the employment share of industry has been less dramatic. It has increased from about 16 percent in the late 1980s to about 20 percent in mid 2000's and has remained there.

\subsubsection{Decomposing overall productivity growth}

Further insight into structural change can be obtained by decomposing overall growth in labor productivity into productivity growth within industries, and that arising from movement of labor from low to high productivity industries. One decomposition often used in the literature is as follows:

$$
\Delta P_{t}=\sum_{i} s_{i, t-k} \Delta p_{i, t}+\sum_{i} p_{i, t} \Delta s_{i, t}
$$


Here the $\Delta$ stands for the difference between time t and t-k, $P$ and $p_{i}$ stand for productivity of the overall economy and of sector $i$, respectively, and $s_{i}$ stands for the employment share of sector $i$. Hence the equation states that overall productivity growth between $t$ and $t-k$ consists of two components: the first is the productivity growth within each sector, weighted by the beginning of period employment shares. The second term is the sum of changes in employment shares, weighted by the end of period sectoral productivity levels. The second term is often called the structural change component.

Such an exercise has already been undertaken for the case of Turkey by Rodrik (2010). Here we update the results with more recent data and provide further details. We are also particularly interested in a comparison between 1990s and 2000s. ${ }^{3}$ The sectoral employment data published by TurkStat follows NACE Rev.1 classification for 1988-2009 period, and NACE Rev.2 for the following years. We converted 18 NACE Rev. 2 branch of activities into 9 NACE Rev.1 branch of activities so that we have 9 "sectors" for 1988-2010. The sectoral GDP data comes from 2 series published by TurkStat. The first series is the sectoral GNP series which follows ISIC Rev. 2 classification and covers 1968-2006 period. The second series is the sectoral GDP series that follows NACE Rev.1.1 classification. It is published for the period 1998-2010. We managed to have an imperfectly consistent sectoral data for both employment and GDP by regrouping both employment and GDP data into the following 9 sectors: agriculture (AGR); mining (MIN); manufacturing (MAN); public utilities - electric, gas, water (PU); construction (CONS); wholesale and retail trade (WRT); transport, communication and storage (TSC); finance, insurance, real estate and business services (FIRE); community, personal and government services (CSPSGS). ${ }^{4}$

The basic decomposition of growth in labor productivity is given in Table 2 for two periodizations, as before. The table shows that movement of labor from low to high productivity sectors has made a significant contribution to overall productivity growth. For the 1990s, almost all productivity growth is due to structural change. In the 2000 s, structural change accounts for more than half of overall productivity change. As discussed by Rodrik (2010), Turkey resembles Asian countries, where the structural change components are often positive, rather than Latin American countries, where the structural change component is negative.

[Table 2 about here]

Averaging over decades hides significant volatility. Atiyas and Bakis (2013) provide the same decomposition on an annual basis. In almost all years (with the exception of 1995 and 2011) where productivity growth has been positive, the contribution of structural change has been positive as well, again pointing to the overall positive contribution of the structural change component to productivity growth. Also, they show that the average labor productivity of individual sectors varies across sectors. The dispersion is quite high, ranging from agriculture

\footnotetext{
${ }^{3}$ Unfortunately we cannot include the 1980s in this comparison as TurkStat does not provide sectoral employment data at this sectoral detail before 1988 .

${ }^{4}$ For details on this grouping see Atiyas and Bakis (2013).
} 
where productivity is about 40 percent of average productivity, to public utilities, and the financial sector (FIRE), where productivity is about three times as high as manufacturing. It can be shown, however, that there is a declining trend in the variance of productivity across sectors. ${ }^{5}$

[Table 3 about here]

Table 3 provides detailed data on the contribution of individual industries to overall productivity growth in the 1990s and 2000s. In each panel the first (last) row shows the percentage point contribution (percentage share) of each sector to the overall average annual productivity growth in that period. ${ }^{6}$ The next two rows decompose that contribution to changes in the sectors' productivity (multiplied by the employment share in the beginning of the period, the "within component") and changes in the sectors' employment share (multiplied by productivity at the end of the period, the "structural change" component). Hence during the period 1990-2001 the highest contribution to overall productivity growth came from the manufacturing industry: almost 34 percent of the overall average annual productivity growth of about 1 percent occurred in manufacturing. In the 2000s the largest contribution came from the manufacturing sector (MAN) and the financial sector (FIRE) accounting each for about 30 percent of overall productivity growth. Note that productivity increase within FIRE has been negative. In FIRE the overall positive contribution comes fundamentally from the structural change component. In fact, looking at the details reveals that the increase in the share of FIRE employment is relatively small; a much higher than average level of productivity gets multiplied by a small increase in employment, resulting in a sizeable structural change component. In MAN the contribution of increase in productivity (the within component) is large, and that of increase in employment share is smaller but still positive.

To summarize the main results so far: Turkey has experienced significant growth in overall labor productivity in the last decade. The increase in labor productivity is respectable in international comparison as well. The country has experienced significant structural change, whereby the employment and value added shares of agriculture has decreased and those of services, and to some extent, of manufacturing have increased. Structural change has made a significant contribution to overall productivity growth, both in the 1990s and in 2000s. In fact, in the period 1990-2001 almost all of overall growth in labor productivity was due to structural change. During the 2000s, both productivity increase within industries and structural change were important in overall productivity growth, accounting for about one third and two thirds of the latter, respectively. Both manufacturing and the finance-real estate sector made significant contributions to overall productivity growth.

\footnotetext{
${ }^{5}$ See the working paper version of this study, Atiyas and Bakis (2013).

${ }^{6}$ Both components scaled by the beginning-of-period overall productivity.
} 


\subsection{Looking at micro data: changes in the size of output and employment}

The previous section showed that structural change contributed significantly to the overall increase in productivity in the 2000s. In this section we look at micro data to see if we can get additional insights into the characteristics of structural change in Turkey.

We start by comparing the size distribution of production over different periods of time. The distribution of output across firms of different size classes may reflect the impact of a number of influences. Smaller firms may have more constrained access to markets because of limited credit, or market foreclosure by larger firms, or other transactions costs that may work to the disadvantage of smaller firms. In environments where political connections are important, larger firms may enjoy more extended political connections that may enable them to access critical resources more easily. This may be especially relevant in Turkey.

The micro data used in this section is the Annual Industry and Service Statistics compiled by TurkStat. For the years 1980-2001 the data set consists of private plants with at least 10 employees and all state owned plants in the manufacturing industry. For the period 2003-2009 the data set contains all 20+ firms plus random samples of 1-19 firms accompanied with sampling weights from almost all non-agriculture industries ${ }^{7}$. For the 2003-2009 period, there is also information on the employment and sales of all plants owned by the firms. In the comparisons in this subsection, years for comparisons were chosen so as not to correspond to crisis years. Also comparisons are carried out only for the manufacturing industry. Table 4 provides data on the share of plants in different size categories of total employment. We use sales from production rather than value added because value added is not available at the plant level for 2003-2009. Also, we assume that the distribution of sales from production across plants in each firm is the same as the distribution of sales across plants in each firm. The data reveals a fundamental change in overall market structure. Whereas plants with more than 500 employees accounted for 47 percent of employment and 57 percent of sales in 1985-86, these ratios have decreased to 22 percent and 35 percent respectively. These are very significant changes. There have been corresponding increases in the shares of smaller plants. For example, the employment share of plants with less than 50 employees has increased from 17 to 37 percent. The share of sales of the same group of plants increased from 11 to 23 percent.

[Table 4 about here]

The table also shows average labor productivity, expressed as sales from production per employee. The average productivity of each size category is expressed as a percentage of the average productivity of firms with 10-19 employees. In all periods, average productivity increases with size. Moreover, the size distribution of average productivity shows remarkable similarity across time periods. The average productivity of 500+ firms is about 2.5-2.6 times

\footnotetext{
${ }^{7}$ For the sectoral coverage of the data set see http://www.turkstat.gov.tr/PreTablo.do?alt_id=1035. Atiyas and Bakis (2014) provide for a detailed description of the data set.
} 
those of 10-19 firms. In most other size categories the gap between average productivity of that group relative to that of 10-19 firms seem to either remain constant or decline by a small amount.

\subsection{Developments in the manufacturing industry}

In this section we report changes in the structure of manufacturing industry. Table 5 shows the evolution of sectoral composition of value added in manufacturing since 1970. The data is taken from the UNIDO data set INDTSAT2, which provides data on 2-digit ISIC manufacturing industries. There is quite a clear pattern across time: The share of some traditional industries, such as food and beverages, tobacco and textiles have declined over time. By contrast, the shares of non-metallic mineral products, machinery and equipment and motor vehicles have increased. The shares of basic metals and fabricated metal products have first declined and then increased. Overall, the table reflects significant structural change in manufacturing and also that this change has accelerated in the 2000s.

\section{[Table 5 about here]}

In order to evaluate these developments and put them into perspective, we can use the approach proposed by UNIDO (2009) and evaluate the degree of "sophistication" of these 2-digit industries and their evolution worldwide. The proposed approach ranks 282 -digit industries according to the weighted average incomes of countries which tend to produce these goods. The ranking is done via an index (originally developed by Hausman, Hwang and Rodrik (2007) to evaluate export goods), called P-soph, ${ }^{8}$ which is the weighted average of aggregate per capita income of all the countries that produce that good, where the weights are equal to the ratio of the value added share of that industry within the total manufacturing value added of that country to the world value added share of that industry. ${ }^{9}$

Table 6 shows the evolution of the global ranks of industries whose share in total manufacturing have increased or decreased in Turkey. We see that food and beverages, textiles and tobacco, whose shares have declined in Turkey ranked low in sophistication and further lost ground in the last two decades. Motor vehicles ranked very high in the 1970s and 1980s but have medium sophistication in the last 20 years. Machinery and equipment still is ranked quite high in terms of sophistication, hence the fact that the share of that industry as increased in Turkey is a positive development. Table 6 also reports that the medical, optical and precision instruments are the globally highest ranking industry. The share of that industry in manufacturing in Turkey is very low.

\footnotetext{
${ }^{8}$ Hausman, Hwang and Rodrik call the index PRODY; see below.

${ }^{9}$ Let us $y_{i}$ denote the real GDP per capita in constant prices (US\$ PPP 2000) in country $i$ producing in sector $j$. Than the Psoph of sector $j$ in country $i$ is given by

$$
\operatorname{Psoph}_{j}=\sum_{i} \frac{x_{i j} / X_{i}}{\sum_{i}\left(x_{i j} / X_{i}\right)} y_{i}
$$
}


[Table 6 about here]

\subsection{Structural change in exports}

When the liberalization and export orientation of the Turkish economy started in 1980, the share of exports in GDP was a mere 5 percent, according to data from World Development Indicators. This share has increased and reached 20-25 percent in GDP in the 2000s. The period of rapid increases in exports relative to GDP was really 1980s and 1990s. By contrast, the 2000s seem a period of stabilization in the export orientation of the country. Nevertheless, since overall the 2000s were a period of rapid growth of GDP, the volume of exports continued to increase: exports have increased from about below 55 billion current USD in 2000-2001 to about 160 billion USD in 2010-2011.

What has really changed in the last decade is the composition of exports. A bird's eye view of this change is presented in Table 7. Between 1996-2000, the share of agricultural goods has decreased from about 9 to about 4 percent, with a corresponding increase in the share of manufactured goods. The real change has occurred within exports of manufactured goods. The share of more traditional exports such as food and beverages and textiles and garments has decreased from a total of almost 50 percent to 25 percent. The increase has come from various manufacturing sectors but most notably from motor vehicles and trailers, machinery and equipment, basic metals, fabricated metal products and rubber and plastic products.

[Table 7 about here]

Atiyas and Bakis (2013), using United Nations trade statistics database, Comtrade, show that the share of export goods with medium technology (UNIDO definition) in total exports has more than doubled from about 15 percent of total exports in 1990 to 30-35 percent in late 2000s. The share of goods with high technology content is very low, about 3-5 percent of total exports. Hence, while there has been quite a substantial change in the composition of Turkey's exports, and while the technology content has increased in the last decade, Turkey has very limited exports of high technology goods.

Recently new measures have been developed to describe the characteristics of countries' export goods. One such measure, often referred to as the "export sophistication index" or EXPY, has been developed by Hausman, Hwang and Rodrik (2007). Intuitively, EXPY measures the "average income level" of the export basket of a country. ${ }^{10}$ A higher EXPY means that the

\footnotetext{
${ }^{10}$ Let $\mathrm{y}_{\mathrm{i}}$ denote the real GDP per capita in constant prices (US\$ PPP 2005) in country $i$. Then, the PRODY of good $j$ is given by

$$
\operatorname{PRODY}_{j}=\sum_{i} \frac{x_{i j} / X_{i}}{\sum_{i}\left(x_{i j} / X_{i}\right)} y_{i}
$$

Using PRODY we can compute EXPY for country $i$ as a weighted index of the representative income associated with exports of country $i$

$$
E X P Y_{i}=\sum_{j}\left(x_{i j} / X_{i}\right) * P R O D Y_{j}
$$
}


export basket of that country consists of goods that are more likely to be exported by richer countries. Atiyas and Bakis (2013) show that Turkey's EXPY has increased over the last 20 years. Nevertheless, Turkey's EXPY is still below those of Mexico, China, Romania and Thailand, to give a few examples.

Another measure developed by Hausman and Hidalgo (2010) is called ubiquity. It measures the extent to which the export basket of a country is made of goods that are "unique". More specifically the index measures, on average how many other countries also export the products exported by a country. The higher the ubiquity index, the higher is the likelihood that the country's export goods are produced by other countries, and hence are less unique. Atiyas and Bakis (2013) show that the ubiquity index of Turkey is higher than a number of countries with similar level of per capita income. Hence Turkey's exports are more "common" than those of Brazil, Thailand, Romania and China.

Taymaz et. al (2011) provide further insights into the characteristics of export growth in the last decade. When one examines products for which Turkey has relatively high market share in 2008, one sees that Turkey is more competitive (as measured by world market share) in products whose total world exports have relatively lower rate of growth between 2002-2008 (p. 70). Furthermore, at the product level, there is a negative correlation between the rate of change of Turkey's market share and the rate of growth of world market share for these products (ibid). Taymaz et. al. (2011) also examine unit prices of exports in the EU15 market. It turns out that over the 2002-2008 period, Turkey's market share in EU15 has increased more for products where the difference between average unit prices of total EU15 imports and those of EU15 imports from Turkey are largest. In other words, Turkey has expanded market share in products where Turkish prices are lower than average EU15 import prices. For example, in the case of motor vehicles, unit prices of imports from Turkey are on average 24 percent lower than average unit prices of overall imports (p. 71). By contrast, there is no negative relation between the average prices of the latest 12 member states of the EU. In other words, Turkey's competitors among the new members of the EU have been able to increase market share without having to reduce their prices (p. 72).

\section{5 "Import dependence" of industrial production}

One of the major macroeconomic problems Turkey has been facing is large current account deficits. There is a widespread perception, especially within the government, that large current account deficits have partly to do with what is considered to be excessive dependence of industrial production to imported intermediate inputs and machinery. The import dependence of

Turkish industry has been examined by Sayg1lı et. al. (2010) in a research paper published by the Central Bank. Saygilı et. al. (2010) document that intermediate goods imports of Turkey have

where weights are the shares of products in the total exports of country $i$. 
increased 2.5 times more than the increase in manufacturing output between 1994-2008. This reflects in part the structural change in manufacturing discussed above. The share of traditional industries such as textiles and garments has decreased and the shares of motor vehicles, basic metals and fabricated metal products in manufacturing have increased. The expanding industries import a larger portion of their intermediate inputs and raw materials. As a result, according to the study, the share of imported inputs and raw materials in total inputs and raw materials has increased from 56 percent in 2002 to 62 percent in 2007.

The study attempts to investigate reasons behind firms' preferences for imported inputs as well as machinery and equipment. It relies on interviews carried out by 145 large firms that represent 50 percent of value added in their sectors (including textiles, garments, motor vehicles, white goods, machinery, basic metals, non-metallic minerals). Firms were asked about why they prefer to import intermediate goods and machinery, rather than procure them from domestic markets. In the case of intermediate goods, about 97 percent of firms surveyed indicated "absence of domestic production", and 75 percent indicated "quality and uninterrupted supply" and "lower cost" as reasons for importing. Only 24 percent indicated "foreign owners" (that is desire to procure from upstream elements of vertically integrated supply chains) as reasons for procuring intermediate inputs from import markets. In the case of machinery, "absence of domestic production" was chosen by 96 percent of firms, "quality and uninterrupted supply" by 72 percent and "lower cost" by 45 percent. Overall, 65 percent of firms indicate "absence of domestic production" as the most important reason for importing machinery, 19 percent indicate "quality and uninterrupted supply" and 8 percent lower cost. The ratios for raw materials and intermediate inputs are 53,19 and 20 percent, respectively.

Taymaz, Voyvoda and Yilmaz (2011) provide further insights for the motor vehicles industry. They calculate contribution to trade balance of parts and components produced for the motor vehicles industry, as well as that of final goods. For final goods (both vehicles used as consumption goods and those used as capital goods), while the contribution to trade balance was negative in 1998, it has become positive in 2002, 2007 and 2009. This of course reflects the increase in exports already mentioned. However, the contribution to trade balance for parts and components has remained negative throughout that period.

\section{Industrial policy}

\subsection{Evolution of the incentive regimes}

While discussing industrial policy in Turkey, it is useful to make a distinction between the period up to the economic reforms that started in 1980 and the period after the reforms. As mentioned above, before 1980, and practically for most of the post-war period, Turkey followed a policy of "import substitution industrialization". This was a highly protected regime, so trade protection was a major component of industrial policy. A crucial aspect of the transformation towards a market-oriented economy in the 1980s was trade liberalization. Quantitative restrictions were 
significantly reduced, especially from 1984 onwards, and were practically eliminated by 1990 . Tariffs were also reduced very significantly. Özler and Y1lmaz (2009) report that "outputweighted average nominal tariff rate for the manufacturing industry declined from $75.8 \%$ in 1983 to $40 \%$ in 1990 and to $20.7 \%$ in 1994 (p. 342)." The trade policy environment was further radically changed by the establishment of the Custom's Union (CU) with the European Union in 1996. Hence especially since the 1990s trade protection has played a much less significant role in Turkey's policies towards industry. ${ }^{11}$ The impact of trade liberalization and the CU on industrial productivity is discussed in section 4.4 below.

Returning to other tools of industrial policy, until 1960s there was not much in terms of providing subsidies to the private sector investments or exports (Eser 2011: 75). ${ }^{12}$ After the coup of 1960 Turkey entered the so-called "planned era" and promotion of investments became a priority. The incentives were initially allocated by the Ministry of Industry and Ministry of Trade. In 1967 the "Bureau for the Development and Encouragement of Investments and Exports" was established under the Prime Ministry. In 1970 the State Planning Organization became responsible for incentive policy, through the formation of the Incentive Implementation Department (Teşvik Uygulama Dairesi, TUD). The department was transferred to the Ministry of Industry and Technology in 1970 and back to the SPO again in 1980. It moved to the Undersecretariat of Treasury and Foreign Trade in the 1990s. The concept of "investment deduction", meaning tax breaks for investments, was first created in 1963 through an amendment in the Income Tax Law. The concept of "Regions with Priority in Development" (RPD) was introduced in 1968, through the designation of 22 provinces as RPD. The "incentive certificate", the document that determines eligibility for incentives, was created during those years as well.

Promotion of investments through incentives was an important policy instrument that has been used in the post-1980 period. An important characteristic of the post-1980 period was that incentives were used not only to increase the overall level of investments but to direct investments to particular sectors. This was first done through a "positive list" of sectors that would be promoted. Later this practice was changed and a "negative list" was created denoting industries that would not be supported. Every year the sectors where investments would be promoted were decided through circulars. Besides priority sectors and regions, investments in organized industrial zones were supported as well.

An important dimension of the policy changes in the 1980s was a heavy emphasis on promoting exports. Indeed, in the 1980s and early 1990s exporters could benefit from a multitude of export incentives (Celasun and Rodrik, 1989; Arslan and van Wijnbergen, 1993). There were export tax rebates, which compensated exporters for indirect taxes. For certain goods, 20 percent of export earnings could be deducted from taxable income. There were subsidized credits. Under

\footnotetext{
${ }^{11}$ For EU countries, tariff rates are zero except for agricultural products. This is of course not true for imports from countries with whom Turkey does not have a free trade agreement. For example, Togan (2003) estimated that the weighted mean tariff rate for such countries was 5.9 percent in 1999.

${ }^{12}$ The only exception is the formation of the Turkish Industrial Development Bank in 1950 with support from the World Bank. The purpose of the Bank was to provide medium and long term credit to industry.
} 
the export-credit-rediscount scheme, exporters holding certificates and reaching minimum levels of exports could obtain preferential credit for up to $25 \%$ of their export commitment at rates far below market lending rates over the entire period. Exporters could benefit from preferential allocation of foreign exchange and duty free imports. Finally, exporters obtained support from the Resource Utilization Support Fund (RUSF) based on export values. This was discontinued in 1986 and after 1987, the Support and Price Stabilization Fund started to provide subsidies on the basis of export volume. This change was designed to reduce the incentive for over-invoicing of exports implied by value-based incentives. According to Arslan and van Wijnbergen (1993) these support schemes added up to about 15-25 percent of exports in 1980-87. Milanovic (1986) calculated that in 1980-84 there were large variations across sectors, ranging in ad-valorem equivalents of exports, from around 10 percent of exports in food and beverages to around 70 percent or above in metal products (quoted in Celasun and Rodrik, 1989). Hence as a general orientation, support in this period was implemented on a selective and sectoral basis.

There has been a controversy about the effect of these subsidies. There were widespread allegations of over-invoicing and corruption, corroborated by both Celasun and Rodrik and Arslan and van Wijnbergen. Regarding the impact of subsidies on volume of exports, Arslan and Wijnbergen found a positive effect, but whose size is much smaller when compared to the effect of real depreciation of the currency that was achieved during the 1980s.

The Resource Utilization Support Fund mentioned above deserves a special attention: First instituted in 1984 (Decision 85/10011) it provided cash grants reaching around 50 percent of investments. ${ }^{13}$ This was actually one of the few cases where the government granted cash support to investments. There seems to be a widespread view that the RUSF did generate substantial investments. ${ }^{14}$ The mechanism was implemented in the fiscally relatively comfortable years of the 1980s. Fiscal conditions became tighter towards the end of the 1980s and the RUSF was discontinued in 1991. Subsidies in terms of cash transfers were completely removed in 1995 (Eser 2003: 79). The incentive system started to rely predominantly on tax exemptions.

Sectoral targeting of incentives continued on and off throughout the first part of the 1990s. Starting in 1995, there was a significant change in the basic logic of the investment incentive system. In 1995 two important things happened. In February Turkey became a member of the World Trade Organization (WTO). In March, Turkey established a customs union with the European Union. Both of these meant that Turkey had to revise its incentive system in line with the WTO and EU requirements. According to the WTO Agreement on Subsidies and Countervailing Measures (SCM), countries cannot adopt measures that are based on export performance or that discriminate in favor of domestic production. Measures that target the production of specific products or sectors are "actionable", that is, may be subject to a legal challenge. By contrast, subsidies that are not "specific" to sectors, and that have horizontal

\footnotetext{
${ }^{13}$ Eser (2003: 78).

${ }^{14}$ For example, Eser (2003:78) states that the RUSF resulted in large investments in the tourism industry such as five star hotels in western and southern regions of Turkey and manufacturing plants (especially textiles) in provinces such as Denizli, Usak, Kahramanmaras and Gaziantep.
} 
objectives such as those for regional development, research and development or environmental protection, are outside the scope of the SCM. The customs union with the EU required that state aid in Turkey be harmonized with state aid rules of the EU.

As a result, starting with 1995 industrial policy moved away from sectoral targeting and started to focus on regional incentives, and more "horizontal" mechanisms such as support for research and development, environmental protection and subsidy programs for small and medium enterprises (SMEs). In the case of exports, subsidies based on export performance were replaced by incentives for participation in trade fairs, certification, product and brand promotion (Yardımc1, n.d.).

Overall, we can also state that since the 1990s there has been a tendency to increase the degree of objectivity in eligibility rules and a reduction in the heterogeneity and discretion in the application of individual instruments. A good example is the investment deduction: In broad terms, the investment deduction or allowance allowed companies to deduct a determined portion of their current year capital expenditures from the corporate tax base of that account year. The ratios varied between 40-100 and even 200 percent (Eser, 2011). Through law No. 4842 of 2003 the ratio was set at 40 percent and was applied in an automatic manner (that is, all investment expenditures became eligible (Eser 2011)). The investment deduction was abolished through law no. 5479 in 2006.

The incentive system evolved further in the 2000s. An important law in this period was Law No $5084^{15}$ of 2004 which had an explicit regional orientation. The purpose of the law was to promote investments and employment in targeted provinces. What is noteworthy about this law is the absence of sectoral selectivity and the rather small set of instruments employed. The Law covered 36 provinces (where yearly GDP per capita was less than USD 1,500 in 2001) and offered newly created firms 80 to 100 percent (for firms in industrial zones) exemption from personal income taxes (capped at the minimum wage) and exemption from employers' social security contributions, and a Treasury subsidy of 20 percent on their electricity bill. The law also provided for allocation of publicly owned land free of charge for firms employing at least 10 workers for at least 5 years. Investments in organized industrial zones were supported more strongly: For example social security contributions and income taxes of firms established in industrial zones were subsidized 100 percent whereas that ratio was only 80 percent for firms outside zones.

The scheme was changed through Law No. 5350 of May 2005. The new law increased the coverage of targeted provinces to 49 , increased the amount of subsidies and changed (in some cases toughened) eligibility requirements. This time to be eligible for subsidies newly created firms had to employ more than 30 workers and old firms had to increase their employment by at least 20 percent. Eventually the coverage of the law was further extended: for example, the law

\footnotetext{
${ }^{15}$ Law No. 5084 on the Encouragement of Investments and Employment and Amendment of Certain Acts, published in the Official Gazette dated 06.02.2004, No. 25365.
} 
was amended so that the personal income tax exemption would include all employees of all enterprises employing at least ten workers (Eser, 2001:109). ${ }^{16}$

A new incentive system was launched in 2009. ${ }^{17}$ This time the purpose was stated as to "direct the savings toward the investments with high added value, to increase the production and employment, to ensure the sustainability of the investment tendency and sustainable development, to encourage large-scale investments with high content of technology and research and development, to increase direct foreign investments, to overcome regional development differences, and to support research and development activities regarding the conservation of the environment". The 2009 regime re-introduced sectoral selectivity. In fact, the 2009 regime differentiated incentives according to regions, sectors and the size of investment. On the regional dimension, one perceived problem with the system introduced through Law 5084 was that among the 49 provinces covered, more advanced provinces attracted higher volume of investments. Hence the 2009 regime divided the provinces of Turkey into four different groups according to their socio-economic development in 2001 and differentiated support instruments and amounts across the groups. Within each region, priority sectors were identified. For example, while in the more developed regions (first and second) the emphasis was on hightechnology industries, priority in the less developed (third and fourth) regions in the south and south-east was placed on agriculture, light manufacturing, tourism, health and education. Finally, a new category "large scale investment" was created under the new regime, whereby investments over minimum specific thresholds in specific sectors also are eligible for incentives.

The system was further changed in 2012. ${ }^{18}$ One important innovation in the new system was the introduction of incentives for "strategic investments". ${ }^{19}$ Accordingly, eligible sectors were defined as those where Turkey's dependence on imports are high (more specifically, where imports represent more than $50 \%$ of domestic demand). Only projects with a minimum of 50 million TL investments generating more than $40 \%$ of local value added will be supported. The 2012 regime divided Turkey into six regions, and in region 6 (the least developed region) all investments are to be promoted. ${ }^{20}$ The new regime also reduced the minimum investment thresholds for the large scale investment incentives. It introduces the notion of "priority investments" in areas such as mining, education, railroads, test facilities and wind tunnel, and priority investments are to be supported by instruments designed for Region 5 even when those investments are carried out in regions 1-4. Organized industry districts have been promoted by most packages. The 2012 package also strengthened incentives that promote investments in

\footnotetext{
${ }^{16}$ Law No 5615.

${ }^{17}$ Decision No. 2009/15199 on state aids towards investments, Official Gazette dated 16.07.2009.

${ }^{18}$ Decision No. 2012/3305 on State aids towards investments, Official Gazette dated 19.06.2012.

${ }^{19}$ In official presentations, the 2009 system is described as standing on three pillars: The "general investment incentives scheme", "the regional investment incentive scheme" and the "large scale investment incentive scheme." The 2012 regime has a fourth pillar, namely the "strategic investment incentive scheme". See "The Framework of New Investment Incentives Program In Turkey" by the Ministry of the Economy at http://www.economy.gov.tr/index.cfm?sayfa=A67B52CC-0629-8F39-A84C6FE830713E30

${ }^{20}$ The least developed region gets larger support. Most importantly, employer and employee social security contributions and personal income taxes (up to a cap) will be exempted for 10 years.
} 
organized industry districts. Joint ventures established by 5 or more partners in an industry and which promote "integration" in the common industry of activity also receive marginally stronger incentives.

The emergence of support for "strategic investment" deserves special attention. This is thought in part as a remedy against what is seen as excessive dependence on imported inputs of industry, which, as discussed above, is in turn seen as partly responsible for large current account deficits inflicting economic growth. To develop remedies to the "import dependence" problem the government initiated an "Input Procurement Strategy" (GITES, Girdi Tedarik Stratejisi), the purpose of which is stated as "achieving stability, efficiency and productivity in the procurement of inputs, reducing import dependence and improving competitiveness of exports". The strategic investments component of the new incentive system is supposed to have grown out of the GITES strategy, with the purpose of reducing imports through projects that aim domestic production of imports. Even though how this component of the new system will be implemented is not clear, the purpose of the scheme seems to be to promote import substitution without resorting to trade barriers.

\section{[Table 8 about here]}

Quantitative data on incentives in Turkey is scarce. According to data in Eser (2011) suggests that the ratio of the value investment projects that obtained incentive certificates to total private fixed capital formation was about $20-25$ percent in the 2000 s. Table 8 provides data on the sectoral distribution of incentives over the 1980-2008 period. The manufacturing industry projects account for about 57 percent of all incentive certificates, 40 percent of investments supported by incentives and 60 percent of employment envisaged under the supported projects. Within manufacturing industry, textiles and apparel account for 33 percent of certificates, and 40 percent of investments and employment. Food and beverages account for 15 percent of certificates, 9 percent of investments and 12 percent of employment. The next important industry is motor vehicles with shares 9, 14 and 7, respectively (Eser, Table 3.4). One could wonder whether the share of manufacturing has increased in the last decade but this does not seem to be the case. Between 2005-2011 the share of manufacturing in the number of certificates, investment volume and employment has been on average 56 percent, 39 percent and 57 percent, respectively. ${ }^{21}$

How can we characterize the incentive system? The absence of major sectoral selectivity in the 2000s lead us to characterize the incentive system as largely "neutral" in the last decade. It was mostly Comparative-Advantage-Facilitating and did not contain any "leapfrogging". ${ }^{22}$ The most recent changes implemented in 2009 and especially in 2012 reflect a change in these characterizations. Especially with the introduction of sectoral orientation, identification of priority investments and strategic investments, the new direction of the incentive regime has

\footnotetext{
${ }^{21}$ Data from the Ministry of Economy website.

${ }^{22}$ See, for example, Lin (2010) for a discussion of Comparative Advantage Facilitating vs. Defying characterizations of industrial policy.
} 
Comparative Advantage Defying characteristics and leapfrogging aspirations. It may be underlined, though, that in the case of "strategic investments", the incentive mechanism encourages some degree of self-selection. That is, instead of specifying specific sectors or products, the eligibility criteria are set as "high import levels", meaning within the set of such industries, it will be up to the private sector to determine which particular products or industries they would like to invest in.

\subsection{Incentives for research and development (R\&D)}

Public support for research and development exists since the 1990s, however resources have been limited until recently. ${ }^{23}$ The main public agencies responsible for conducting R\&D related support programs are the Scientific and Technological Research Council of Turkey (TUBITAK), Technology Development Foundation of Turkey (TTGV) and Small and Medium-size Industry Development Organization (KOSGEB) affiliated with the Ministry of Industry and Trade. In addition, the Ministry of Finance, with administrative assistance of TUBITAK, provides tax incentives for R\&D investment, through an exemption from corporate taxes of 40 percent of companies' total R\&D expenditures. Among these agencies, TUBITAK is by far the most important source of public funds (Table 9).

[Table 9 about here]

TUBITAK conducts several programs but the private sector is specifically targeted by the industrial R\&D support programs managed jointly by the Technology and Innovation Support Programs Directorate of TUBITAK (TUBITAK-TEYDEB) and the Undersecretariat of Foreign Trade (DTM). Here DTM provides the funds and TUBITAK serves as a referee institution (Tandoğan and Pamukçu, 2011). The objective of these programs is to enhance the international competitiveness of industrial companies through higher R\&D and innovation (ibid). Expenditures from this program have increased substantially since 2005, from about 81 million USD in 2004 (PPP) to about 357 million USD (PPP) in 2009. Number of project applications has similarly increased from about 360 in 2004 to about 1500 in 2009 (TUBITAK 2011, p. 17).

The TUBITAK-TEYDEB programs support the projects in the following areas: (i) machinery and manufacturing technologies, (ii) electrical and electronics, (iii) information technologies, (iv) materials, metallurgical and chemical technologies, (v) biotechnology, agriculture, environmental and food technologies. About 50-60 percent of eligible expenses are supported through grants. (Tandoğan and Pamukçu, 2011, p. 4). In 2007 TUBITAK-TEYDEB also launched a new program targeting specifically small and medium enterprises (SMEs) providing grants up to 75 percent of eligible SMEs' first two R\&D projects (ibid). Tandoğan and Pamukçu show that the share of SMEs in total project applications increased significantly after the new launch of the new program.

${ }^{23}$ This section draws on Tandoğan and Pamukçu (2011). 


\subsection{Evaluation of industrial policy in Turkey}

We start the evaluation of industrial policy in Turkey by reviewing the impact of trade liberalization that occurred in the 1980s and 1990s. Özler and Y1lmaz (2009) examine the impact of reduction in trade barriers during the period 1983-1996. They estimate plant-level total factor productivity (TFP) and compare weighted average of productivity growth across import competing, export oriented and non-traded industries. They find that productivity growth is highest in import competing industries. ${ }^{24}$ They then estimate the effect of declines in nominal protection rates on plant-level productivity. They find statistically significant productivity improvements resulting from reductions in protection rates. Taymaz and Yllmaz (2007) focus on the period 1985-2000. Their main findings are as follows: overall total factor productivity growth declines after the CU. However, TFP growth in import competing sectors is positive after the CU. They then undertake a regression analysis and find that when they regress plant level TFP on (lagged) import penetration rates, the effect of the latter is positive even after the $\mathrm{CU}$. Hence these studies suggest increase in imports pushed firms to increase their productivity.

We now turn to the incentive system. The Turkish incentive system can be evaluated on a number of dimensions. Possibly the most important dimension is the evaluation of its impact, which is not an easy thing to do for a thorough evaluation has to come to grips with the counterfactual. Here we first summarize several studies that attempt to examine the impact of the various incentive schemes.

Ersel and Filiztekin (2008) undertake an evaluation of the incentive programs for the period 1980-2000. They proxy sectoral intensity of incentives through total volume of investment certificates to the actual investment volume. They measure the impact of this variable on sectoral productivity growth, employment growth and investment, controlling for sector fixed effects. They find that investment incentives either have no effect on these variables, and in the few cases where there is a significant effect (as in the case of investment), it is negative. They also report findings from a survey carried out on businesses that benefited from incentives: 64 percent of respondents indicated that they would have decided to invest even if incentives were not offered. This finding points to sizeable deadweight losses.

Regarding the incentives embodies in Laws No. 5084 and 5350 the OECD (2008, p. 144) has reported that the number of registered workers in eligible provinces increased by 66 percent between 2003-2007, while only by 47 percent in other provinces. This, by itself is not proof of positive impact since eligible provinces could have been on a higher growth path to start with for other reasons. Betcherman et. al. (2010) use a difference-in-difference approach to measure the impact of subsidies provided by laws No. 5084 and 5350 on provincial employment and number of establishments both in levels and growth rates. The study uses data compiled by the Social security Administration at the level of provinces, containing information on the number of registered workplaces, registered employees, total taxable earnings that are subject to

\footnotetext{
${ }^{24}$ Import competing industries are those where the import penetration rates (imports as a share of sectoral output) is larger than 15 percent.
} 
contributions, and social security premiums. The authors find that the subsidy programs did lead to faster employment growth in the eligible provinces. Depending on specification and constitution of control groups, additional employment varies between 5-10 percent for Law No. 5084 and 10-15 percent for Law No. 5350. However, Betcherman et. al. also find that the number of jobs subsidized were much larger than the estimated net gains in the number of jobs: between 47 and 78 percent of subsidized jobs under the Law No. 5084 programs and between 27 and 46 percent of jobs created under the Law No. 4350 program would have been created without the subsidy. Again, these findings reflect sizeable deadweight losses in the impact of these incentives.

Can we say anything about the sectoral impact of incentives? We have already mentioned that Ersel and Filiztekin find no such impact for the period 1980-2000. We have also documented above the rather serious change in the composition of manufacturing value added especially in the 2000s. The change in the composition of exports during the 2000s documented above was even more impressive. However, for most of the 2000s the incentive system did not have a sectoral selectivity; the latter has been re-introduced after 2009. Hence from this we can conclude that at least in the 2000s, the changes in the sectoral composition of manufacturing industry and exports did not come about as a result of deliberate targeting of industrial policy. This does not necessarily mean that the incentive system did not have a sectorally differentiated impact. For example, in a study on Chinese firms Aghion et. al. (2012) find that "if subsidies are allocated to competitive sectors (as measured by the Lerner index) or allocated in such a way as to preserve or increase competition (i.e if they are more dispersed across firms in the sector), then the net impacts of subsidies on productivity or productivity growth become positive and significant. In other words, targeting can have beneficial effects depending on both the degree of competition in the targeted sector and on how the targeting is done." This raises the possibility that even neutrally designed incentive schemes may have non-neutral effects across sectors. Moreover, it could be the case that incentives may have affected overall investments beyond their sectoral destination. These are interesting questions warranting further research.

Regarding the impact of research and development support programs, Tandoğan and Pamukçu (2011) investigate the effect of TUBITAK - TEYDEB support program over the period 20032005 and 2003-2006. Their data set contains a total of 237 observations of firms that have received subsidies. They use the propensity score matching method to pair firms that receive and do not receive $R \& D$ subsidies. They supplement this with difference-in-differences to control for macroeconomic trends and unobserved heterogeneity. They find that for the period 20032005 they find a positive effect of subsidies on R\&D intensity (R\&D expenditures divided by total sales) and R\&D expenditure per employee of beneficiary firms but not for the period 20032006. They also test whether subsidies have an impact on output variables such as export intensity, sales, labor productivity and wage rate but they do not find any effect, perhaps due to the fact that such subsidies take a longer time to have any impact (Tandoğan and Pamukçu 2011, p. 14). Taymaz and Özçelik (2008) undertake a similar study for the period 1993-2001 and they 
also find an albeit smaller effect of public support programs on private R\&D intensity (in their case defined as R\&D expenditure divided by output).

Another set of dimensions through which the incentive system can be evaluated has to do with institutional characteristics. Especially in the 2000s, it seems the Turkish incentive system has been implemented on a relatively non-discriminatory basis. It does not seem that there has been a systematic and widespread effort to favor, for example, politically linked firms (although a few significant episodes of favoritism, more linked to privatization rather than the incentive system, have appeared in the press). Eligibility criteria have been quite clear and objective. Hence in its description of the 2012 regime, OECD 2012 states: "The new system preserves a number of positive features of the preceding regime: i) eligible beneficiaries are identified on the basis of explicit criteria and rules, minimizing room for administrative discretion; ii) no distinction is made according to firm ownership (public versus private or domestic versus foreign); and iii) no trade protection is involved, in contrast to incentive policies applied in a number of other emerging countries". We will see whether the implementation of instruments targeting "strategic investments" will be carried out on a non-discriminatory basis as well. However, the system so far does have a number of important weaknesses.

One important weakness has been volatility: namely important components of the incentive regime have changed very frequently, even in the 2000s. This makes the system unpredictable. Regarding transparency: all incentives granted are published in the Official Gazette, an important achievement in terms of transparency. But there has been very little transparency in terms of process. Incentives have been determined through Cabinet Decisions without any justifications or public consultation.

Another important problem is one of coordination: There have been many disparate programs with few links between them. For example, R\&D subsidies may have little impact in promoting innovation or investments in new sectors, unless there is a complementary effort to develop skilled labor in the relevant industries. Hence incentives may need to be complemented by education and training policies to develop the necessary human capital.

Filiztekin, Barlo and Özgür (2011) emphasize another characteristic of the regional dimension of the incentive systems: Namely that the incentive system is excessively centralized, excessively hierarchical and does not try to engage the active participation of regional stakeholders. Moreover, whatever participation exists is biased in favor of representation by business. A more effective structure would allow more active platforms for public consultation at the local level and more participation by local stakeholders in the decision making process.

Finally and maybe most importantly, there is no impact evaluation. Ideally the incentive system should be set up so as to include data collection efforts that can be used to evaluate the impact of the various components. Lack of impact evaluation is a major weakness of the incentive system. 


\section{Conclusion}

In this paper we examined various aspects of structural change in Turkey and provided an overview of industrial policy in the last three decades. We have shown that there has been a significant increase in labor productivity in the 2000s. Decomposition of the increase in labor productivity using aggregate data shows that the structural change component, that is, the reallocation of labor from low productivity (agriculture) to high productivity (industry and services) sectors has made a significant positive contribution to aggregate productivity change, a result already established by Rodrik (2010). We further show that, various sorts of data problems notwithstanding, micro data pertaining to the 2000 s also reveal an overall positive contribution of reallocation. Micro data also reveals a significant redistribution of sales and employment across firms of different sizes: The shares in output and employment of largest firms have declined over time.

There has also been a significant change in the composition of exports. The share of traditional exports such as textiles and garments has decreased over time and the shares of medium-level technology products (such as motor vehicles, basic metals and machinery) have increased. At the same time, we have also showed that the share of high-technology products is still very low. The degree of sophistication of exports basket of Turkey is still low compared to a number of comparator countries such as Mexico, China, Romania and Thailand. Also, those industries whose contribution to exports has increased over time also exhibit higher dependence on imports of intermediate inputs such as raw materials and components.

Regarding industrial policy, we have documented the crucial role of trade liberalization and customs union with the EU. We have shown that sectoral selectivity of investment and employment incentives has decreased over time and has made a comeback recently. We have argued that over time the incentive system has become less discretionary and eligibility criteria have become quite objective and transparent. Regarding impact, we have reported some positive impact on regional employment in the 2000s, and positive impact of research and development incentives. However, in the 2000s the incentive system was not designed to achieve sectoral selectivity, although that does not preclude the possibility that its impact across sectors may have varied depending on sectoral characteristics such as the degree of competition.

We have identified several weaknesses in the institutional characteristics of the incentive regime. We have especially underlined the fact that the incentive system does not have any mechanisms for evaluation. 


\section{Bibliography}

Acar, Ozan and Eser Çağlar (2012) An Assessment of the new Incentive Package, TEPAV Policy Note No. N201221.

Aghion,Philippe, Mathias Dewatripont, Luosha Du, Ann Harrison and Patrick Legros (2012) "Industrial Policy and Competition," NBER Working Paper No. 18048.

Akat, Asaf Savaş and M. Ege Yazgan (2013) “Observations on Turkey's recent economic performance", Atlantic Economic Journal 41 1-27

Arslan, Ismail and Sweder van Wijnbergen (1993) "Export Incentives, Exchange Rate Policy and Export Growth in Turkey" The Review of Economics and Statistics, 75 (1) 128-133

Atiyas, Izak 2012 "Economic Institutions and Institutional Change in Turkey during the Neoliberal Era," New Perspectives on Turkey, No.47, 45-69

Atiyas, İzak and Ozan Bakis (2014). "Firm Dynamics and Job Creation in Turkey,” work in progress.

Atiyas, İzak and Ozan Bakis (2013). "Structural Change and Industrial Policy in Turkey" REF Working Paper No 2013-3, http://ref.sabanciuniv.edu/sites/ref.sabanciuniv.edu/files/str_ch_refwp.pdf

Atiyas, Izak and Ozan Bakis (2011) Türkiye'de Büyümenin Kısıtları: Bir Önceliklendirme Çalışması, TUSIAD Publication, No. 2011/11/519.

Baysan, Tercan and Charles Blitzer (1990). "Turkey's Trade Liberalization in the 1980s and Prospects for its Sustainability" Tosun Arıcanlı and Dani Rodrik (eds). The Political Economy of Turkey, London: Macmillan.

Betcherman, G, N. Meltem Daysal and Carmen Pages (2010) "Do Employment Subsidies Work? Evidence From Regionally Targeted Subsidies in Turkey”, Labor Economics 17 (4) 710-722.

Celasun, M., and Dani Rodrik (1989) "Debt, Adjustment and Growth: Turkey," in J. Sachs (ed.), Developing Countries' Debt, Chicago: University of Chicago Press and NBER.

Ersel, Hasan and Filiztekin, Alpay, (2008) "Incentives or compensation? Government support for private investments in Turkey", Industrial policy in the Middle East and North Africa: rethinking the role of the state, Galal, Ahmed (ed.), Cairo, Egypt: The American University in Cairo Press, $35-50$

Ersel, Hasan and Fatih Özatay (2008) "Fiscal Dominance and Inflation Targeting: Lessons from Turkey," Emerging Markets Finance \& Trade, 44 (6) pp. 38-51.

Eser, Emre (2011) Türkiye'de Uygulanan Yatırım Teşvik Sstemleri ve Mevcut Sistemin Yapısına Yönelik Öneriler, Sate Planning Organisation Expert Thesis, SPO: Ankara.

Filiztekin, Alpay, Mehmet Barlo and Özgür Kıbrıs (2011). Türkiye'de Bölgesel Kalkınma: Farklılıklar, Bağıntılar Ve Yeni Bir Mekanizma Tasarımı, TURKONFED Publication. 
Hausmann, R. and C. A. Hidalgo (2010) Country diversification, product ubiquity and economic divergence, HKS Faculty Research Working Paper 10-045.

Hausmann, R., J. Hwang and D. Rodrik (2007) "What you export matters" Journal of Economic Growth, 12 (1) 1-25.

Kılınç, Mustafa, Kılınç Zübeyir and M. İbrahim Turan (2012) "Resilience of the Turkish Economy During the Global Financial Crisis of 2008," Emerging Markets Finance \& Trade, 48 (Supplement 5), pp. 19-34.

Lin, Justin Yifu, 2010, "New Structural Economics: A New Framework for Rethinking Development", Policy Research Working Paper \# 5197, Washington D.C., World Bank. Milanovic, Branko (1986). Export incentives and Turkish manufactured exports, World Bank staff working paper No 768 .

Ministry of the Economy (2012) "The Framework of New Investment Incentives Program In Turkey" www.economy.gov.tr

OECD (2008) OECD Economic Surveys: Turkey. OECD (2012) OECD Economic Surveys: Turkey.

Özler, Şule and Kamil Yılmaz (2009) "Productivity response to reduction in trade barriers: evidence from Turkish manufacturing plants", Review of World Economics 145 (2) 339-360. Rodrik, Dani (2010) "Structural Transformation and Economic Development" TEPAV: Ankara. Saygıll, Şeref, Cengiz Cihan, Cihan Yalçın and Türknur Hamsici (2010) Türkiye İmalat Sanayiin İthalat Yapısı, TCMB Çalışma Tebliği 10/02.

Tandoğan, Vedat Sinan and Mehmet Teoman Pamukçu (2011). "Evaluating Effectiveness of Public Support to Business R\&D in Turkey Through Concepts of Input and Output Additionality" ERF Working Paper No 593.

Taymaz, Erol ve Kamil Yilmaz (2008) Integration with the Global Economy: The Case of Turkish Automobile and Consumer Electronics Industries, Commission on Growth and Development, Working Paper No 37.

Taymaz, Erol ve Kamil Y1lmaz (2007) "Productivity And Trade Orientation: Turkish Manufacturing Industry Before And After The Customs Union", The Journal of International Trade and Diplomacy 1 (1), 127-154.

Taymaz, Erol, Ebru Voyvoda and Kamil Yılmaz (2011) Uluslararası Üretim Zincirlerinde Dönüşüm ve Türkiye'nin Konumu, Ekonomik Araştırma Forumu Çalışma Raporları Serisi Yayın No: EAF-RP/11-01.

Togan, Subidey (2003) "Trade and Foreign Exchange Regime in Turkey", in Competitiveness in the Middle Eastern and North African Countries, ed. by S. Togan and H. Kheir-El-Din, 
Economic Research Forum for the Arab Countries, Iran and Turkey Research Report Series, Cairo: ERF, 73-130.

TUBITAK (2011). Science, technology and Innovation in Turkey: 2010.

World Bank (2009) Turkey - National Innovation and Technology System: Recent Progress and Ongoing Challenges, Report No. 48755-TR, Word Bank: Washington, D.C.

Yardımcı, Atilla M. (n.d.) “Türkiye'de Teşvikler ve Uygulaması”, Undersecretariat of Treasury General Directorate of Incentives and Implementation. 


\section{Tables}

Table 1: Average Growth of Labor Productivity (\% per annum)

\begin{tabular}{|l|l|l|l|}
\hline $1981-1990$ & 3.42 & $1981-1989$ & 3.01 \\
\hline $1991-2000$ & 2.08 & $1990-2001$ & 1.86 \\
\hline $2001-2010$ & 2.36 & $2002-2010$ & 3.24 \\
\hline
\end{tabular}

Source: Calculated from TurkStat data. Arithmetic averages of annual log differences.

Table 2: Decomposition of aggregate productivity growth (\%)

\begin{tabular}{|l|c|c|c|c|}
\hline & $1990-1999$ & $2000-2010$ & $1990-2001$ & $2002-2010$ \\
\hline Within component & 0.00 & 1.22 & -0.03 & 1.28 \\
Structural change & 1.01 & 1.78 & 1.28 & 2.22 \\
total & 1.00 & 3.00 & 1.24 & 3.50 \\
\hline
\end{tabular}

Source: Authors' calculations based on TurkStat data.

Table 3: Decomposing average annual productivity growth: The sectoral details (1990-2010)

\begin{tabular}{|c|c|c|c|c|c|c|c|c|c|c|c|}
\hline & & AGR & MIN & MAN & PU & CONS & WRT & TSC & FIRE & CSPSGS & All \\
\hline \multirow{4}{*}{ 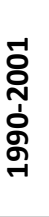 } & $\begin{array}{l}\text { Perc. point contrib. to } \\
\text { LP growth }\end{array}$ & -0.12 & -0.02 & 0.43 & 0.07 & -0.07 & 0.14 & 0.40 & 0.33 & 0.09 & 1.24 \\
\hline & Within component & 0.19 & 0.11 & 0.07 & -0.07 & -0.11 & -0.37 & 0.29 & -0.26 & 0.12 & -0.03 \\
\hline & Structural change & -0.31 & -0.12 & 0.36 & 0.14 & 0.04 & 0.50 & 0.11 & 0.59 & -0.03 & 1.28 \\
\hline & Perc. sh. in LP growth & -9.44 & -1.25 & 34.30 & 5.59 & -6.02 & 10.90 & 32.14 & 26.61 & 7.17 & 100 \\
\hline \multirow{4}{*}{ 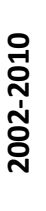 } & $\begin{array}{l}\text { Perc. point contrib. to } \\
\text { LP growth }\end{array}$ & -0.05 & 0.01 & 1.03 & 0.09 & 0.22 & 0.50 & 0.64 & 1.06 & 0.00 & 3.50 \\
\hline & Within component & 0.54 & 0.02 & 0.78 & -0.02 & -0.05 & 0.39 & 0.35 & -0.63 & -0.11 & 1.28 \\
\hline & Structural change & -0.59 & -0.01 & 0.25 & 0.11 & 0.27 & 0.11 & 0.29 & 1.69 & 0.11 & 2.22 \\
\hline & Perc. sh. in LP growth & -1.39 & 0.34 & 29.29 & 2.57 & 6.29 & 14.25 & 18.28 & 30.35 & 0.01 & 100 \\
\hline
\end{tabular}

Source: Authors' calculations based on TurkStat data. 
Table 4: Evolution of size distribution of plants in manufacturing

\begin{tabular}{|c|c|c|c|c|c|c|c|}
\hline & & \multicolumn{6}{|c|}{ Employment size category (number of employees) } \\
\hline & & $10-19$ & $20-29$ & $50-99$ & $100-249$ & $250-500$ & $500+$ \\
\hline \multirow{3}{*}{ share in employment (\%) } & $1985-6$ & 6.0 & 11.2 & 8.6 & 12.9 & 14.8 & 46.6 \\
\hline & $1995-6$ & 4.0 & 12.4 & 10.4 & 19.2 & 16.7 & 37.3 \\
\hline & $2006-7$ & 11.6 & 21.1 & 11.9 & 20.1 & 13.0 & 22.4 \\
\hline \multirow{3}{*}{ share in sales from production (\%) } & $1985-6$ & 2.9 & 7.6 & 6.5 & 10.5 & 15.7 & 56.7 \\
\hline & 1995-6 & 2.1 & 7.5 & 7.9 & 15.5 & 19.4 & 47.7 \\
\hline & 2006-7 & 6.7 & 16.2 & 10.1 & 18.0 & 14.5 & 34.5 \\
\hline \multirow{3}{*}{$\begin{array}{l}\text { average productivity (relative to } \\
\text { plants with } 10-19 \text { employees) }\end{array}$} & 1985-6 & 1.00 & 1.39 & 1.57 & 1.68 & 2.19 & 2.50 \\
\hline & 1995-6 & 1.00 & 1.18 & 1.49 & 1.58 & 2.28 & 2.50 \\
\hline & 2006-7 & 1.00 & 1.33 & 1.47 & 1.56 & 1.94 & 2.67 \\
\hline
\end{tabular}

Source: Authors' calculations based on TurkStat micro data.

Table 5: Sectoral composition of value added in manufacturing industry in Turkey $(\%)$

\begin{tabular}{|l|r|r|r|r|r|}
\hline & 1970 & 1980 & 1990 & 2000 & 2006 \\
\hline Food and beverages & 16.4 & 14.0 & 11.9 & 12.5 & 10.7 \\
\hline Tobacco products & 9.8 & 4.3 & 4.0 & 5.2 & 1.7 \\
\hline Textiles & 13.8 & 14.2 & 11.2 & 10.5 & 11.4 \\
\hline Wearing apparel, fur & 0.7 & 1.1 & 3.7 & 4.6 & 6.4 \\
\hline Leather, leather products and footwear & & & & 0.6 & 1.0 \\
\hline Wood products (excl. furniture) & 0.9 & 1.1 & 0.6 & 0.7 & 1.2 \\
\hline Paper and paper products & 2.6 & 1.9 & 1.9 & 1.8 & 2.0 \\
\hline Printing and publishing & 1.9 & 0.9 & 1.5 & 3.6 & 1.8 \\
\hline Coke,refined petroleum products,nuclear fuel & 15.4 & 14.5 & 17.3 & 12.0 & 2.1 \\
\hline Chemicals and chemical products & 6.5 & 10.2 & 9.9 & 10.1 & 6.8 \\
\hline Rubber and plastics products & 2.8 & 3.0 & 2.7 & 3.6 & 4.8 \\
\hline Non-metallic mineral products & 5.2 & 6.8 & 8.2 & 6.6 & 9.4 \\
\hline Basic metals & 10.6 & 9.9 & 6.9 & 5.4 & 9.6 \\
\hline Fabricated metal products & 4.5 & 3.6 & 3.1 & 3.1 & 4.7 \\
\hline Machinery and equipment n.e.c. & 4.0 & 4.7 & 4.9 & 5.0 & 7.9 \\
\hline Office, accounting and computing machinery & & & & 0.2 & 0.1 \\
\hline Electrical machinery and apparatus & 1.4 & 4.3 & 5.1 & 2.6 & 3.1 \\
\hline Radio,television and communication equipment & & & & 2.1 & 1.8 \\
\hline Medical, precision and optical instruments & 0.1 & 0.1 & 0.3 & 0.6 & 0.5 \\
\hline Motor vehicles, trailers, semi-trailers & 2.8 & 5.0 & 6.0 & 6.6 & 8.7 \\
\hline Other transport equipment & & & & 0.7 & 1.5 \\
\hline Furniture; manufacturing n.e.c. & 0.5 & 0.4 & 0.6 & 1.7 & 2.8 \\
\hline Recycling & & & & & 0.0 \\
\hline Total manufacturing & 100.0 & 100.0 & 100.0 & 100.0 & 100.0 \\
\hline
\end{tabular}

Source: UNIDO 
Table 6: Sophistication ranks of ISIC 2-digit industries

\begin{tabular}{|l|r|r|r|r|r|}
\hline & 1970 & 1980 & 1990 & 2000 & 2006 \\
\hline Food and beverages & 16 & 16 & 20 & 20 & 20 \\
\hline Tobacco & 18 & 18 & 23 & 23 & 23 \\
\hline Textiles & 17 & 17 & 22 & 21 & 21 \\
\hline Wearing apparel, fur & 14 & 10 & 19 & 19 & 19 \\
\hline Non-metallic mineral products & 13 & 13 & 18 & 18 & 17 \\
\hline Basic metals & 5 & 8 & 8 & 6 & 16 \\
\hline Machinery and equipment n.e.c. & 1 & 2 & 5 & 4 & 2 \\
\hline Medical, precision and optical instruments & 6 & 1 & 6 & 1 & 1 \\
\hline Motor vehicles, trailers, semi-trailers & 4 & 5 & 11 & 11 & 12 \\
\hline Furniture; manufacturing n.e.c. & 9 & 12 & 12 & 16 & 18 \\
\hline
\end{tabular}

Source: Calculated from UNIDO data

Table 7: Composition of exports (\%)

\begin{tabular}{|l|r|r|r|}
\hline & 1996 & 2000 & 2010 \\
\hline AGRICULTURE AND FORESTRY & 9.27 & 5.97 & 4.33 \\
\hline MINING AND QUARRYING & 1.59 & 1.44 & 2.36 \\
\hline MANUFACTURING & 88.38 & 91.87 & 92.61 \\
\hline Food products and beverages & 10.57 & 6.61 & 5.89 \\
\hline Tobacco products & 0.41 & 0.44 & 0.26 \\
\hline Textiles & 16.44 & 16.61 & 9.60 \\
\hline Wearing apparel & 20.80 & 19.50 & 9.32 \\
\hline Luggage, saddlery and footwear & 0.95 & 0.68 & 0.58 \\
\hline Products of wood and cork & 0.30 & 0.23 & 0.50 \\
\hline Paper and paper products & 0.54 & 0.59 & 1.05 \\
\hline Printing and publishing & 0.21 & 0.15 & 0.12 \\
\hline Coke, petroleum products and nuclear fuel & 1.12 & 1.08 & 3.65 \\
\hline Chemicals and chemical products & 5.36 & 5.03 & 5.01 \\
\hline Rubber and plastic products & 2.20 & 2.81 & 4.29 \\
\hline Other non-metallic minerals & 3.36 & 4.04 & 3.50 \\
\hline Manufacture of basic metals & 9.62 & 8.09 & 12.67 \\
\hline Manufacof fabricated metal prod(exc machinery) & 1.99 & 2.38 & 4.37 \\
\hline Manufacture of machinery and equipment & 3.57 & 4.95 & 7.96 \\
\hline Office, accounting and computing machinery & 0.09 & 0.23 & 0.12 \\
\hline Electrical machinery and apparatus & 3.32 & 2.97 & 4.27 \\
\hline Communication and apparatus & 1.36 & 3.46 & 1.71 \\
\hline Medical, precision and optical instruments, watche & 0.24 & 0.27 & 0.36 \\
\hline Motor vehicles and trailers & 4.20 & 6.28 & 13.05 \\
\hline Other transport & 0.67 & 3.18 & 1.46 \\
\hline Furniture & 1.07 & 2.27 & 2.88 \\
\hline
\end{tabular}

Source: TurkStat 
Table 8: Investment incentives: sectoral distribution 1980-2008

\begin{tabular}{|c|c|c|c|c|c|c|c|c|}
\hline Sector & $\begin{array}{l}\text { No. of } \\
\text { Documents }\end{array}$ & $\%$ & $\begin{array}{l}\text { Investment } \\
\text { Volume } \\
\text { current } \\
\text { million } \\
\text { USD) }\end{array}$ & $\%$ & $\begin{array}{l}\text { Investment } \\
\text { volume } \\
\text { (million USD, } \\
2008 \text { prices) }\end{array}$ & $\%$ & $\begin{array}{l}\text { Employment } \\
\text { (thousand) }\end{array}$ & $\%$ \\
\hline Agriculture & 4,863 & 5.9 & 8,395 & 1.0 & 13,203 & 1.0 & 133 & 2.8 \\
\hline Mining & 3,037 & 3.6 & 10,699 & 1.3 & 16,731 & 1.3 & 189 & 3.9 \\
\hline Manufaturing & 47,427 & 57.3 & 350,064 & 41.6 & 509,664 & 40.0 & 2,901 & 60.5 \\
\hline Energy & 998 & 1.2 & 77,035 & 9.1 & 123,019 & 9.7 & 46 & 1.0 \\
\hline Services & 26,485 & 32.0 & 396,098 & 47.0 & 611,152 & 48.0 & 1,524 & 31.8 \\
\hline Total & 82,810 & 100.0 & 842,290 & 100.0 & $1,273,769$ & 100.0 & 4,792 & 100.0 \\
\hline
\end{tabular}

Source: Eser (2011)

Table 9: Public R\&D Support for Enterprises in Turkey (million USD)

\begin{tabular}{|l|r|r|r|}
\hline & 2006 & 2007 & 2008 \\
\hline TUBITAK & 215.0 & 215.0 & 175.0 \\
\hline UFT & 42.0 & 63.5 & $\mathrm{n} / \mathrm{a}$ \\
\hline KOSGEB & 5.4 & 4.6 & 6.5 \\
\hline TTGV & 35.6 & 35.4 & 35.5 \\
\hline Ministry of Industry and Trade & 11.0 & 16.9 & 17.6 \\
\hline Total & 319.0 & 353.4 & 252.6 \\
\hline
\end{tabular}

Source World Bank: 2009 (UFT: Undersecretariat of Foreign Trade.) 